\title{
Ba-ferrite Particulate Media for Linear Tape System
}

\author{
O. Shimizu, T. Harasawa, R. Suzuki, H. Suzuki, N. Yamazaki, A. Musha, \\ Y. Murata, M. Sueki, T. Nishida, and H. Noguchi \\ Recording Media Research Laboratories, \\ FUJIFILM Corporation, 2-12-1 Ohgi-cho Odawara, Kanagawa 250-0001, Japan
}

\begin{abstract}
Two types of Ba-ferrite particulate media used in technical demonstrations that achieved 6.7 Gbit/in ${ }^{2}$ in 2007 and $29.5 \mathrm{Gbit} / \mathrm{in}^{2}$ in 2010 were compared by focusing on differences in their magnetic particle properties and tape characteristics. The results revealed that the difference in SNR between these two media could be explained by the difference in the particle volume and the orientation of the easy axis. The difference in the surface profile of these two media affected their frictional and stictional behavior without affecting their read/write characteristics in the short wavelength region. The long-term chemical stability of Ba-ferrite particulate media was also investigated using a Battelle Class II environment. The results indicated that Ba-ferrite particulate media have superior resistance to chemical corrosion compared to conventional metal particulate media.
\end{abstract}

Key words: magnetic recording, Ba-Ferrite, particulate media, linear tape system

\section{Ba-ferrite 磁性体を用いたリニアテープシステム用塗布型媒体}

清水 治・原沢 建・鈴木涼太・鈴木宏幸・山崎信夫・

武者敦史・村田悠人・居樹 実・西田徹二・野口 仁

富士フイルム (株) 記録メディア研究所, 神奈川県小田原市扇町 2-12-1（テ250-0001）

\section{1.はじめに}

世界のデジタルデータ量はとどまることなく増え続けている. International Data Corporation (IDC) によれば, 2009 年は世界 的な不況であったにも関わらず年率にして $62 \%$ も増加を示し， つい 800 Exa Byte $\left(10^{18}\right.$ byte)に達した. また，今後もとどまる ことなく 2020 年には 35 Zetta Byte (10 21 byte) に達する見込みと のことである ${ }^{1)}$.このように増え続ける情報の保存媒体として, 安 価であること, 長期保存に対する信頼性が高いこと, などの点で 磁気テープが選択されており, 必然的に高密度化への要求は高い. この要求に応えるべく，これまで，さまざまな研究が行われてい る 2) 16). このような中で, 最近までリニアテープシステムは, 年 率 40 \% ，ほぼ 2 年で 2 倍のペースで容量増加を続けてきた. こ の記録密度向上は，主にメタル磁性体の微細化によって達成され ている. しかし，近年この記録密度上昇トレンドに鈍化の傾向が 現れてきている.これは, メタル磁性体における保磁力の発現が, その針状形状に由来しており, 微細化が進むにつれて磁気特性を 維持することが困難になってきていることが一つの理由である.

これを克服する手段としては結晶磁気異方性を，その保磁力の起 源とする粒子の採用が考えられ， Ba-ferrite(以下 BeFe)は適切な 結晶磁気異方性を持つ粒子として古くから研究されている 17), 18).

Fig. 1 に面記録密度に関するハードディスクとリニアテープシス テムの製品ベースでのトレンド及びリニアテープシステムでの技 術デモンストレーションでのトレンドを示す. リニアテープシス テムの製品ベースでの記録密度上昇が鈍化しているのとは対照的 に，その技術デモンストレーションにおける面記録密度上昇はむ しろ，従来の製品ベースでの上昇トレンドさえも凌駕する傾向を 示している. Fig. 1 中に示す Demo A ${ }^{5}$ 及ひびDemo B ${ }^{15}$ はいずれ も $\mathrm{BaFe}$ 磁生体を用いた塗布型媒体で実現されたもので，それぞ

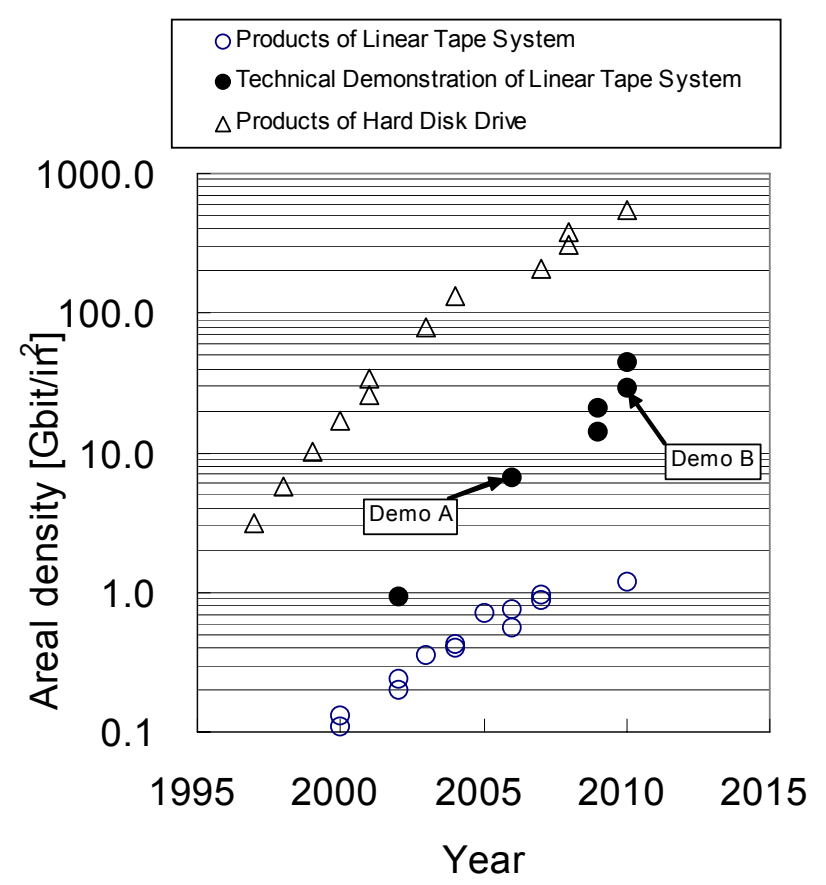

Fig. 1 Areal density trends in linear tape systems and hard disk drives. Open circles: Linear tape system products. Solid circles: Technical demonstration of linear tape systems. Triangles: Hard disk drive products.

れ6.7 Gbit/in² 及び29.5 Gbit/in ${ }^{2} の$ 面記録密度達成を示したもので ある(以下DemoA のシステムを System A, Demo B のシステムを System B と記す). これらは, リニアテープシステムとしての走 行マージン(トラッキング位置再現性) の実測結果も踏まえた検討 
Table 1 Comparison of operating points between Systems A and B.

\begin{tabular}{|c|c|c|c|}
\hline & System A & System B & ratio \\
\hline Linear density [kBPI] & 400 & 518 & 1.3 \\
\hline Track density [kTPI] & 17 & 57 & 3.4 \\
\hline Reader width $[\mu \mathrm{m}]$ & 0.5 & 0.2 & $1 / 2.5$ \\
\hline Track margin $[\mu \mathrm{m}]$ & 1.0 & 0.25 & $1 / 4$ \\
\hline Areal density [Gbit/in²] & 6.7 & 29.5 & 4.4 \\
\hline Channel & $\begin{array}{c}\text { 32-state- } \\
\text { DD-NPML }\end{array}$ & $\begin{array}{c}\text { 16-state- } \\
\text { DD-NPML }\end{array}$ & - \\
\hline
\end{tabular}

結果であり，BaFe 磁生体を用いた記録媒体の高記録容量化一の 実用的完成度の高さを示したものである. 本報告では, これら 2 つの報告で用いられた媒体の差異と両者の性能の関係を明確にし， 今後の媒体開発の指針とすると共に，併せて BaFe 媒体の長期保 存に対する化学的安定性についての評価結果を報告する.

\section{System A と System B の比較}

\section{1 オペレーティングポイント}

Table 1 に System A (6.7 Gbit/in²) 及び System B (29.5 Gbit/in²) 両者のオペレーティングポイント比較の一覧を示す. System A では，線記録密度 400 kBPI，トラック密度 $17 \mathrm{kTPI}$ で $6.7 \mathrm{Gbit} / \mathrm{in} 2$ を達成していたが, System B では線記録密度で 1.3 倍の $518 \mathrm{kBPI}$ ，トラック密度で 3.4 倍の $57 \mathrm{kTPI}$ を実現し，面記 録密度として 4.4 倍の $29.5 \mathrm{Gbit} / \mathrm{in}^{2}$ を達成している. この, トラ ック密度の向上には, 電磁変換特性の向上に伴う再生トラック幅 の低減のみではなく, トラックマージンの低減効果(1/4)の寄与も 大きい. 電磁変換特性の向上による分は, 線記録密度 1.3 倍と再生 トラック幅 $1 / 2.5$ 即ち，記録ビットサイズで $1 / 3.25$ である.

Fig. 2 に, ループテスタを用いて, 摺動速度 $4.1 \mathrm{~m} / \mathrm{s}$, 再生トラ ック幅 $0.5 \mu \mathrm{m}$, シールド間距離 $0.12 \mu \mathrm{m}$ の $\mathrm{GMR}$ ヘッドで測定し た Tape A 及びTape B の SNR の線記録密度依存性を示寸．この 測定における, アンプノイズ及びヘッドノイズは十分に小さく, ここで示寸ものは媒体の SNR とみなして良い. 線記録密度 259 $\mathrm{kFCI}(518 \mathrm{kBPI}$ に対応) における両媒体の SNR 差は約 $3.5 \mathrm{~dB}$ である. 記録ビットサイズ $1 / 3.25$ の達成はこの媒体性能差 $3.5 \mathrm{~dB}$

Table 2 Comparison between Particles A and B. Volumes were obtained from TEM observations and magnetic properties were measured by VSM.

\begin{tabular}{c|c|c}
\hline & ParticleA & Particle B \\
\hline Volume, V [nm3] & 2100 & 1600 \\
\hline Coercivity, Hc [kA/m] & 183 & 207 \\
\hline$\sigma s[\mathrm{Am} 2 / \mathrm{kg}]$ & 52 & 48 \\
\hline
\end{tabular}

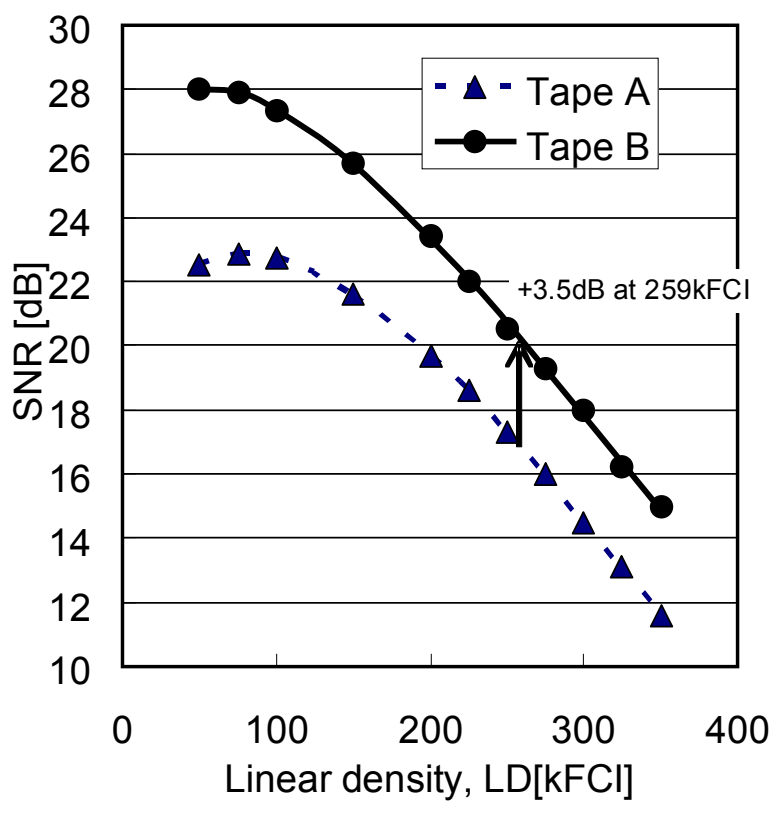

Fig. 2 Dependence of SNR on linear density for Tape A used in 6.7-Gbit/in² demonstration (dashed line) and Tape $\mathrm{B}$ used in 29.5-Gbit/in ${ }^{2}$ demonstration (solid line).

とヘッド性能の向上の結果達成したものである. 厳密には, System A で用いた channel が 32-state DD-NPML (data-dependent noise-predictive, maximum-likelihood)検出で あったが，System B で用いた channel は，実装上より現実的な 16-state DD-NPML である. この channel の差も System B の電 磁変換特性向上によって補われていると考えられる. ここで，も し必要なトラックマージンの低减がなく, System A と System B で同一であり, System Bでも $1 \mu \mathrm{m}$ のトラックマージンが必要で あると仮定すると, System B で達成できるトラックピッチは, System B の再生トラック幅の $0.2 \mu \mathrm{m}$ と System A のトラックマ ージン $1.0 \mu \mathrm{m}$ の和の $1.2 \mu \mathrm{m}(21 \mathrm{kTPI})$ であり, 達成しうる面記箓 密度は高々 $11 \mathrm{Gbit} / \mathrm{in}^{2}$ 程度になってしまう。このトラックマージ ンの改善は, トラッキングを行うアクチェータの高性能化の寄与 もあるが，媒体とへッドの走行性改善による効果も非常に大きい．

\section{2 磁性体}

System A で用いられた BaFe 磁性体Particle A と System B で 用いられた BaFe 磁生体 Particle B の比較を Table 2 に示寸. 体 積 $V$ は透過型電子顕微鏡(TEM)観察結果から板径 $D$ と板厚 $t$ を測 定し, 六角板状と仮定して,

$$
V=\frac{3 \sqrt{3}}{8} D^{2} t
$$

から計算したものである. また, 保磁力 Hc と磁化量 $\sigma$ は VSM に よって測定した值である. Particle A の平均体積が $2100 \mathrm{~nm}^{3}$ であ るのに対して, Particle BはSNR 向上を目的に微細化しており， Particle A の $76 \%$, 即ち $1600 \mathrm{~nm}^{3}$ に低減している. 筆者らは, 
Table 3 Comparison of magnetic properties between Tapes A and B.

\begin{tabular}{c|c|c}
\hline & Tape A & Tape B \\
\hline Perpendicular direction & & \\
Coercivity HcP $[\mathrm{kA} / \mathrm{m}]$ & 215 & 231 \\
Squareness ratio SQP & 0.69 & 0.86 \\
\hline Longitudinal direction & & \\
Coercivity HcL [kA/m] & 159 & 119 \\
Squareness ratio SQL & 0.39 & 0.22 \\
\hline $\mathrm{SQP}_{\mathrm{P}}-\mathrm{SQ}_{\mathrm{L}}$ & 0.30 & 0.64 \\
\hline
\end{tabular}

$1500 \mathrm{~nm}^{3}$ から $2200 \mathrm{~nm}^{3}$ の各種体積の $\mathrm{BaFe}$ 磁生体粒子を用いて 同一条件下で，テープを作成し体積と SNR の関係を調査した ${ }^{12}$. その結果は, 粒子性ノイズを前提とした理論值

$$
S N R \propto 10 \log (1 / V)
$$

とよく対応していた. 即ち, 今回の Particle Aから Particle B と磁性体の体積を 76 \%減少させることによる SNR 向上は $1.2 \mathrm{~dB}$ 程度と推定される.

\section{3 配向}

System A で用いられた媒体 Tape A と System B で用いられた 媒体 Tape B の比較を Table 3 に示寸．Tape B はテープ製造の乾 燥工程で垂直磁界を印加し配向制御を行ったため, 垂直方向の角 型比 SQP が 0.86 に達し, 逆に長手方向の角型比 $\mathrm{SQ}_{\mathrm{L}}$ は 0.22 まで 低下している. 一方, Tape A では製造時において特に積極的制御 は行わなかったが，若干垂直方向の角型比が長手方向の角型比よ りも大きくなっている. これは, 粒子の形状(板状)の影響で, 塗布 によって重直方向に配列しや寸くなった効果と考えられる. 両者 のTEM 断面図を Fig. 3 に示す. TapeA は粒子の向きがほとんど ランダムなのに対して, Tape B は, 多くの粒子で板面が摺動面と 平行に配列し，その結果，粒子の横断面のみが観察されており， 容易軸(板面に垂直方向)が垂直方向に配向しているのがわかる. $\mathrm{BaFe}$ 媒体をモデル化し, 配向のみを変化させた場合の SNR の変 化をマイクロマグネティックシミュレーションにより計算した. モデルの詳細は文献 13)を参照されたい. 結果を Fig. 4 に示す. 横 軸は，垂直配向の程度を表すパラメータとして，垂直方向の角型 比 $\mathrm{SQP}$ と長手方向の角型比 $\mathrm{SQL}$ の差（SQP-SQL）を取り，縦軸 に SNR のシミュレーション結果をプロットしたものである. Table 3 に示寸通り, Tape A は SQP $-\mathrm{SQ}_{\mathrm{L}}=0.30$ であり, Tape B は $\mathrm{SQP}-\mathrm{SQ}_{\mathrm{L}}=0.64$ である. このシミュレーション結果より, この 配向差によって得られた SNRの向上は+ $2 \mathrm{~dB}$ 程度と推定される.

\section{4 表面性及び摺動性能}

Tape A 及び Tape B の表面形状を光干涉型表面形状粗さ計 (Optical Interferometric Profiler：OIP) と原子間力顕微鏡(Atomic Force Microscope:AFM)によって測定した平均表面粗さRa と十
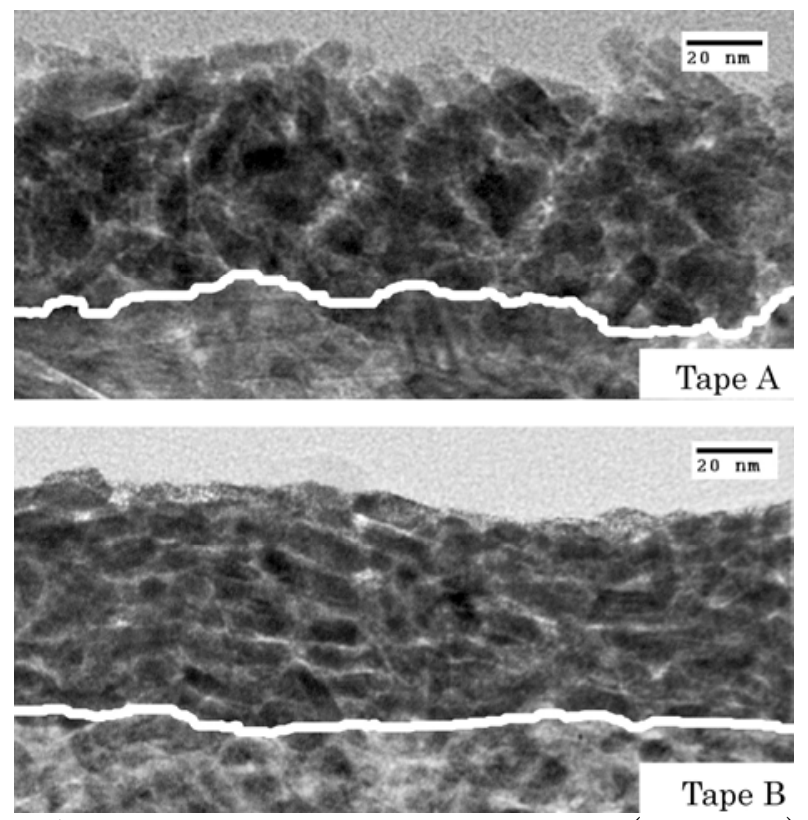

Fig. 3 Cross-sectional TEM image of Tape A (unoriented) and Tape B (perpendicularly oriented).

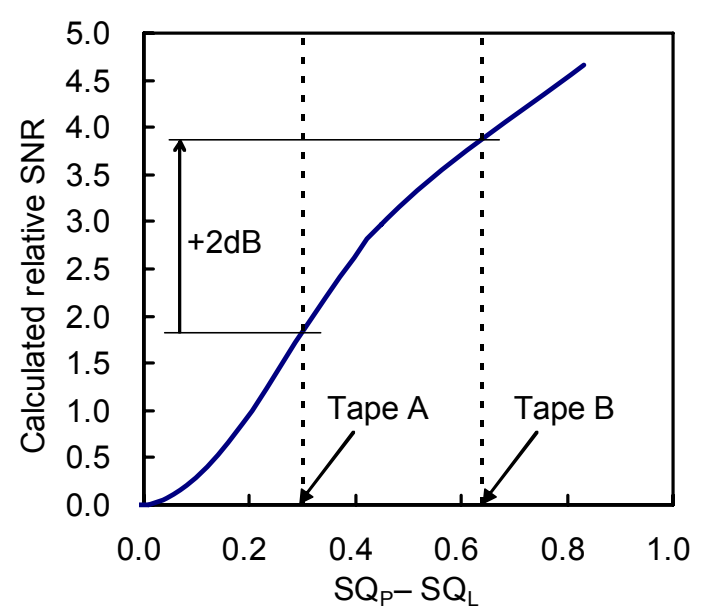

Fig. 4 Dependence of simulated SNR on orientation. SQP and SQL correspond to squareness ratios in perpendicular and longitudinal directions.

Table 4 Surface roughness measured with optical interferometric profiler (OIP) and atomic force microscope (AFM).

\begin{tabular}{c|c|c}
\hline & Tape A & TapeB \\
\hline Optical interferometric profiler & & \\
Ra [nm] & 2.1 & 0.7 \\
Rz [nm] & 23 & 7 \\
\hline Atomic force microscope & & \\
$\operatorname{Ra}[\mathrm{nm}]$ & 2.0 & 2.1 \\
$\mathrm{Rz}[\mathrm{nm}]$ & 39 & 32 \\
\hline
\end{tabular}



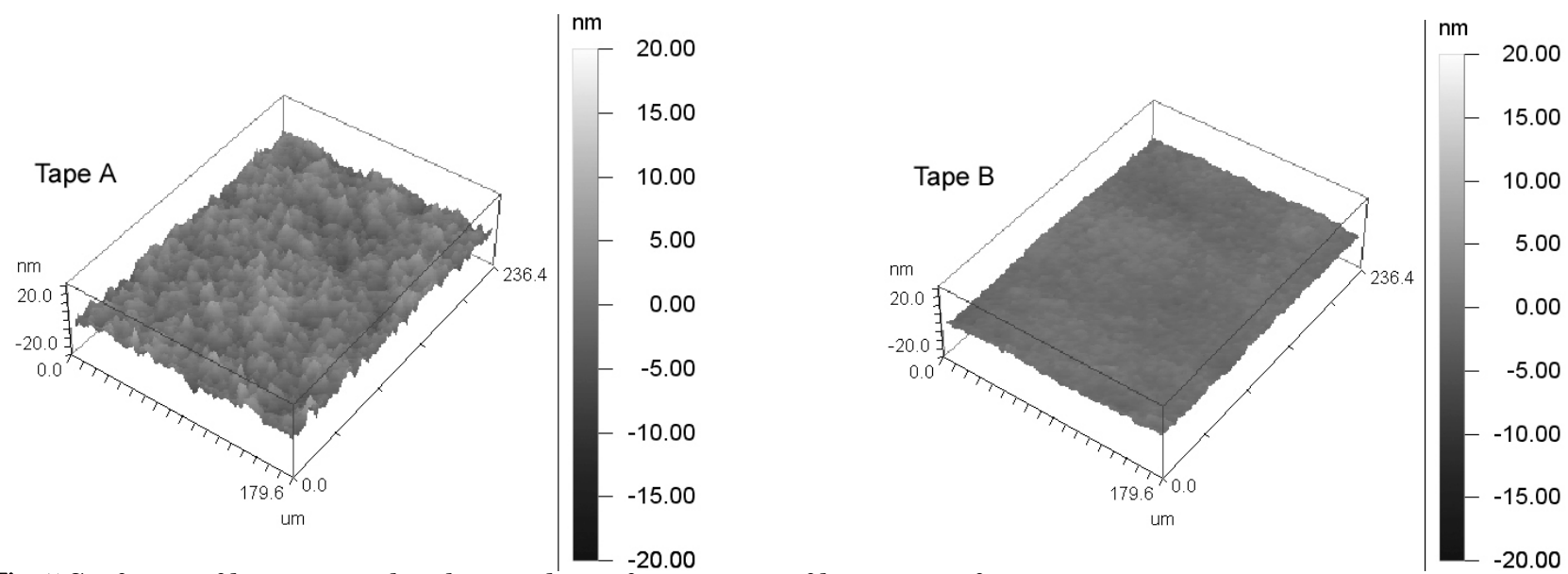

Fig. 5 Surface profiles measured with optical interferometric profiler in area of $180 \mu \mathrm{m}$ x $240 \mu \mathrm{m}$.
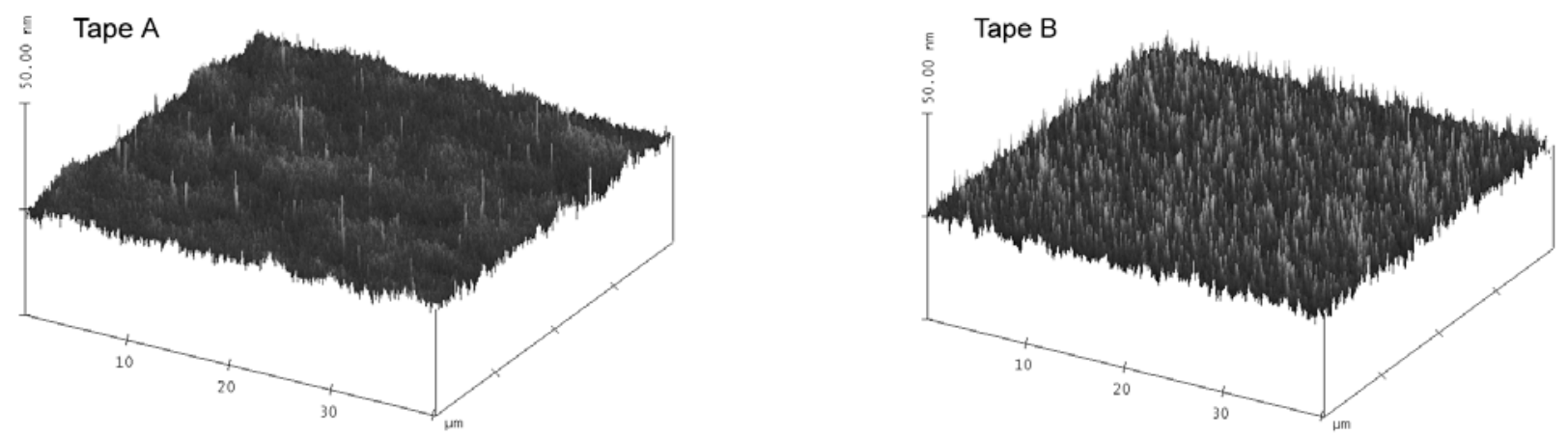

Fig. 6 Surface profiles measured with atomic force microscope in area of $40 \mu \mathrm{m}$ x $40 \mu \mathrm{m}$.
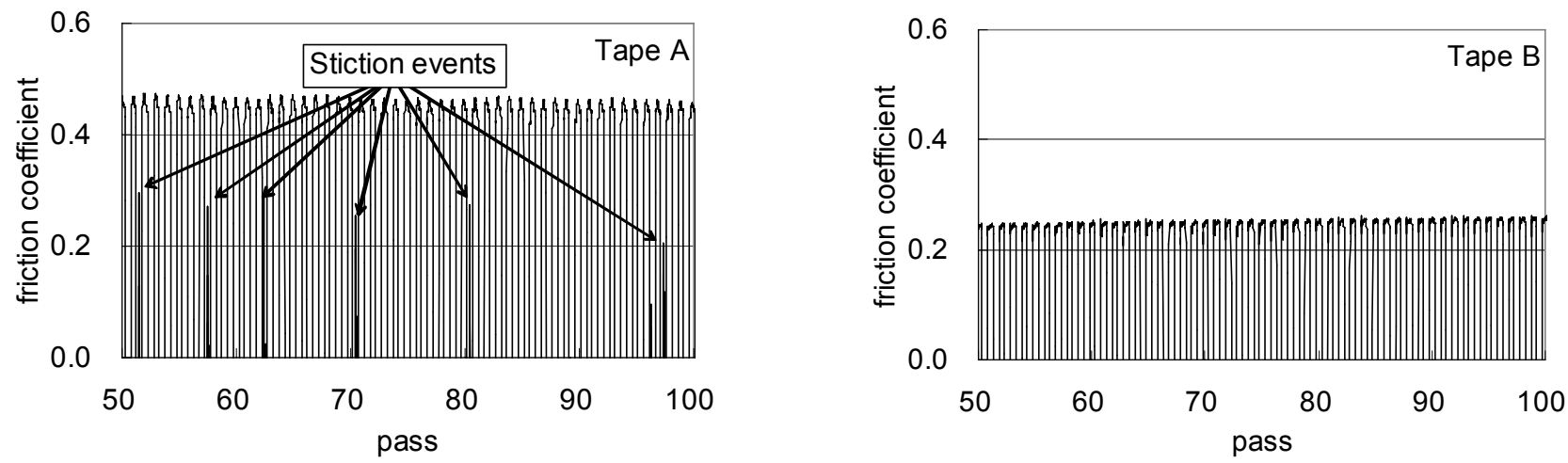

Fig. 7 Frictional coefficient measured with AlTiC at speed of $14 \mathrm{~mm} / \mathrm{s}$ and back tension of $0.98 \mathrm{~N}$. Figures are plotted from 50 to 100 reciprocatory motions. Six stiction events were observed at points indicated in Tape A figure.

点平均粗さ Rz を Table 4 に，またそれぞれのプロファイルを Fig. 5 及びFig. 6 に示す. OIP による測定は, $180 \mu \mathrm{m}$ x $240 \mu \mathrm{m}$ の比 較的大きな面積を測定したもので，広い領域のウネリを表すもの であるが，サブミクロン以下の分解能は無いため，小さな突起は 測定されていない. 一方AFM による測定は $40 \mu \mathrm{mx} 40 \mu \mathrm{m}$ の領 域を測定したもので，微小突起が測定可能であるが大きな広い領 域での変化は測定できない. Table 4 の数字で比較すると, OIPの
測定結果からはTape B に比較して Tape A の粗さが目立つ結果と なっているが, AFM の結果は同等の Ra となっている. これに対 応し, Fig. 5 の OIP プロファイルは, Tape B の平滑さが際立つ結 果となっている一方で, Fig. 6 の AFM プロファイルを見ると, Tape A と比較して, Tape Bは, 非常に多数の微小突起によって 粗面化されていることが分かる. 即ち, Tape B はウネリの無い面 にたくさんの微小突起が形成されており，この面形状によって， 
Table 5 Test condition for gas environmental test.

\begin{tabular}{c|c}
\hline \multicolumn{2}{c}{ Battelle Class II conditions } \\
\hline $\mathrm{Cl}_{2}$ concentration & $10 \mathrm{ppb}$ \\
\hline $\mathrm{NO}_{2}$ concentration & $200 \mathrm{ppb}$ \\
\hline $\mathrm{H}_{2} \mathrm{~S}$ concentration & $10 \mathrm{ppb}$ \\
\hline Relative humidity & $70 \%$ \\
\hline Temperature & $30{ }^{\circ} \mathrm{C}$ \\
\hline
\end{tabular}

摺動特性の大幅な改善を実現している. Fig. 3 のTEM 像では, この微小突起は確認されていない.これは，この微小突起の面密 度が，数平方ミクロンに 1 個程度であり，局所的な TEM 観察に 現れていないためである. Fig. 7 に, TapeA 及びTape B の摺動 テストの結果を示す．これは，0.98 N (100gf）の荷重をかけて， 速度 $14 \mathrm{~mm} / \mathrm{s}$ という低速領域で, 直径 $3 \mathrm{~mm}$ の $\mathrm{AlTiC}$ 部材に対し 180 度巻きつけで, $45 \mathrm{~mm}$ の長さを往復摺動させた時の歪ゲージ にかかった負荷 $x[\mathrm{~N}]$ の変化を,

$$
\mu=\frac{1}{\pi} \ln \left(\frac{x}{0.98}\right)
$$

で摩擦係数に換算した值をパス回数に対してプロットしたもので ある(Fig. 7 では50 パスから 100 パスまでを示している). 通常の 摺動状態であれば, 引つ張り摺動時は歪ゲージに印加される負荷 $x$ は荷重 0.98 に摺動負荷が加わり 0.98 以上の值となり，(3)式で換 算された值は正の值を，戻り時は摺動負荷が差し引かれるので負 の值になるが，ここでは正の值のみをプロットしている. Tape A の摩擦係数は 0.5 近い值を示しているのに対して, Tape B では摺 動を繰り返しても 0.25 程度を維持している. また, Tape A では, グラフ図中 Stiction events と示す 6 箇所で不連続な負荷変動が観 察されている.これは，戻り摺動時に張り付きが発生し，戻り動 作中にこの張り付きが開放され，荷重の落下に伴い急激な負荷上 昇が発生した場所である. 一方Tape B では全てのパスで定常の摩 擦挙動が観察されており, 張り付きの発生はなく, 安定した走行 が実現していることが分かる．最も簡単な摩擦係数の低減方法は 媒体の摺動面を粗面化することである. しかし，この場合，必ず スペーシングの増大を招く. Tape Bでは，微小突起による粗面化 と長周期のウネリを除去することを同時に実現し，ヘッドと媒体 間のスペーシングの増大を招くことなく摩擦係数の低減を実現す ることを目指したものである. Fig. 2 の線記録密度特性からわか るように Tape A と Tape B の高線記録密度領域での応答はほぼ平 行移動であり, また, 両者の磁性層厚が Fig. 3 のTEM 像から明 らかなように，共に $70 \mathrm{~nm}$ 程度と同一であることを考慮すれば, Tape A と Tape B のスペーシングに大きな差がないことが推察さ れる. 実際, 出力の波長特性から, 実効的スペーシング (磁気的ス ペーシング: $\mathrm{d}$ と遷移幅パラメータ: $\mathrm{a}$ の和 $\mathrm{d}+\mathrm{a}$ ）を見積もった ${ }^{19)}$. その結果, TapeAのd+a は $30.3 \mathrm{~nm}$, Tape B は $28.7 \mathrm{~nm}$ と, む しろ若干ではあるが, Tape BがTapeAよりも小さい值を示した.
(a)BaFe tape-before test

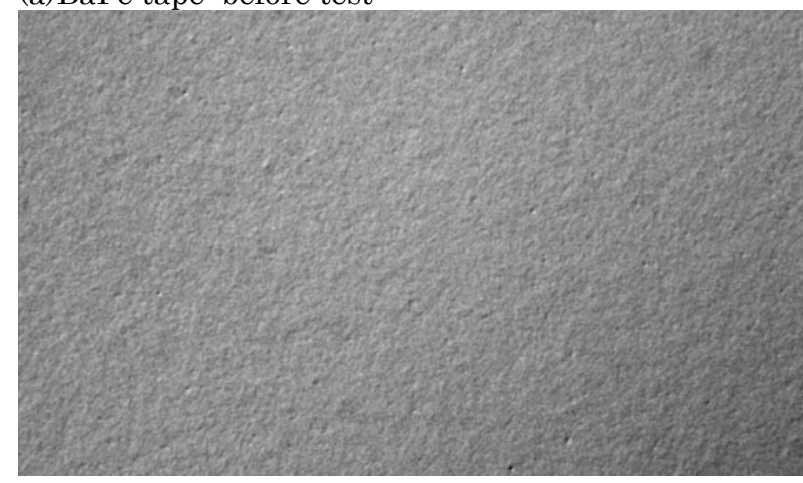

(b)BaFe tape-after Battelle Class II 14 days test

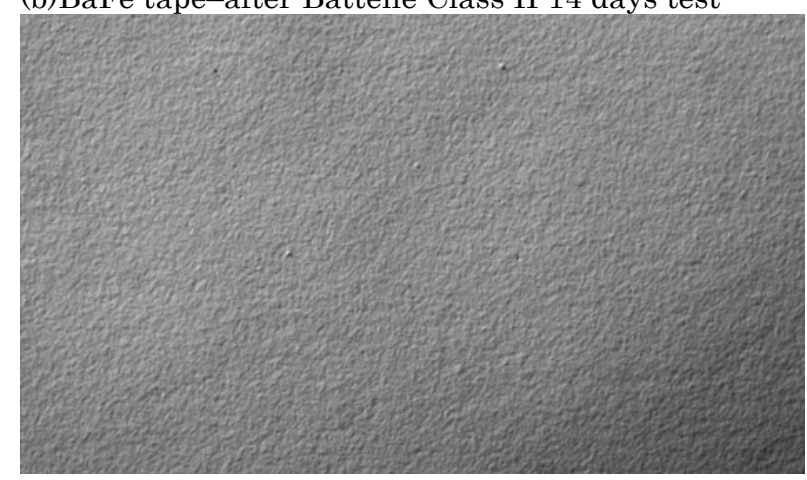

(c)MP tape-before test

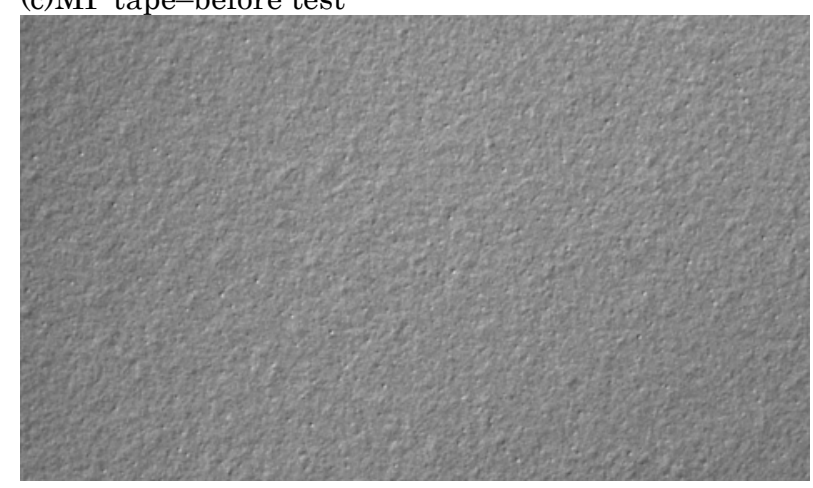

(d)MP tape- after Battelle Class II 14 days test

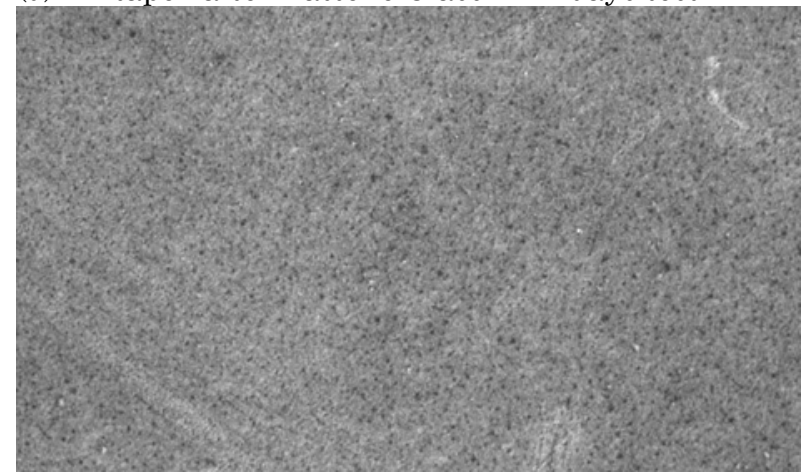

Fig. 8 Tape surfaces observed with differential interference microscope. (a) BaFe tape before test, (b) BaFe tape after test, (c) MP tape before test, and (d) MP tape after test. Environmental test was conducted using Battelle Class II condition. 
Table 6 Change in Mrt (remanent magnetization $\mathrm{x}$ thickness) value in Battelle class II test.

\begin{tabular}{c|c|c|c}
\hline & $\begin{array}{c}\text { Before } \\
{[\mathrm{mA}]}\end{array}$ & $\begin{array}{c}\text { After } \\
{[\mathrm{mA}]}\end{array}$ & Ratio \\
\hline BaFe tape (bare) & 3.1 & 3.1 & 1.00 \\
\hline MP tape (bare) & 19.5 & 12.5 & 0.64 \\
\hline MP tape (in cartridge) & 21.4 & 21.7 & 1.01 \\
\hline
\end{tabular}

つまり，Tape B の表面形状は，スペーシングの増大を招くことな く，摺動特性の大幅な改善を実現していると言える.

\section{3. 長期保存安定性}

現在最も利用されている磁気テープはメタル(MP)テー プであり，MP テープは長期にわたり磁気テープの中心的 役割を果たしている. 1985 年に利用が開始された放送用メ タルテープ MII は 25 年たった現在でも十分利用可能であ り，その長期保存安定性は，実際の利用において証明され ているといっても良いだろう。今後, 新規素材として BaFe を用いた磁気テープを市場導入していくためには, その長 期安定性の確認が必須である.もともと酸化物である $\mathrm{BaFe}$ は比較的安定な化合物であり一般的な温湿度環境テストで は変化しないと想定される。そこで，腐食性ガスを用いた 加速環境による腐食テストとして Battelle Class II 環境に よるテストを行った。これは, Battelle 研究所によって開 発された環境テストのひとつ20)で，温湿度管理されていな い室内環境での腐食を加速していると考えられており，こ れまでも磁気テープのテストに利用されている 21,22 . 比較 の為に, 市場実績がある MPテープと同時にテストした.

Table 5 にテスト環境を示す.この環境下に BaFe テープに ついては表面を剥き出しにした状態で，MP テープについ ては表面を剥き出しにした状態とカートリッジに入れられ た状態の二通りで, 14 日間放置した. 加速比率については, 幾つかの見解があるが, 概ね 400〜 1000 倍である ${ }^{23)}$. 従っ て今回の 14 日間のテストは， 15 年～ 38 年に相当する. 表 面を剥き出しにした場合のテスト前後のテープ表面を微分 干渉顕微鏡で撮影した結果を Fig. 8 に, 残留磁化・厚さ積 の変化を Table 6 に示す. 通常磁気テープはカートリッジ 内で巻かれており，ほとんど外部の大気に接触することが ないことを考慮すると, 表面を剥き出しにした状態は相当 に過酷な環境である. 実際, 実使用において何ら問題のな いMPテープでも, 表面が変化し, 腐食した状態が Fig. 8 (d) から観察されている. また, Table 6 に示すように, MPテ ープでは，このテストの前後で磁化量は大きく低下した。

しかし，Fig. 8 (a)及び(b)に示すように BaFeテープ表面は ほとんど変化することなく，テス卜前後での磁化量も同一 であった。この結果は $\mathrm{BaFe}$ テープの化学的安定性が極め
て高いことを意味している.カートリッジ内の(リーダテー プ直後の)MPテープは全く腐食せず, テスト前後で磁化量 変化も無かった。

\section{4. まとめ}

リニアテープシステムとして面記録密度 $6.7 \mathrm{Gbit} / \mathrm{in}^{2}$ 及び

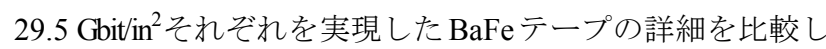
た。両テープを同一条件で測定した SNR 差(媒体のみの $\mathrm{SNR}$ 差)は $3.5 \mathrm{~dB}$ であった。出力の波長特性から見積もら れた両者の実効的スペーシング $(\mathrm{d}+\mathrm{a})$ はほとんど同一であ り, $3.5 \mathrm{~dB}$ の差は, 両者の磁性体粒子の体積差による向上 分 $1.2 \mathrm{~dB}$ と垂直配向による向上分 $2.0 \mathrm{~dB}$ で, ほぼ達成して いると考えられる. 但し, Tape B の摺動面のウネリ(比較的 長周期凹凸)の低さや, 磁性層と下層との界面の平滑性の改 善(Fig. 3 の TEM 断面図参照)もノイズ特性に影響を与えて いると推定される。しかし，今回の解析では，これらの影 響を評価することは出来ていない。今後，ノイズスペクト ルの解析などを通してこれらの影響を明確にしていきたい. 一方, 面記録密度 $29.5 \mathrm{Gbit} / \mathrm{in}^{2}$ 実現の為には, 電磁変換特性 の改善だけではなく，トラッキングマージンの $1 \mu \mathrm{m}$ から $0.25 \mu \mathrm{m}$ と大幅な低減を必要としている.これには, 走行性 能改善に伴う走行トラック位置の再現性向上が大きな役割 を果たしているが，これは，ウネリの少ない面にたくさん の微小突起を形成することによって, 電磁変換特性を犠牲 にすることなく摺動性改善を実現した結果である。また， 今後の $\mathrm{BaFe}$ テープの市場導入に向けて, その化学的安定性 について市場実績がある MP テープと比較して評価した. 評価環境には Battelle Class II 環境を用いて 14 日間のテスト を行った. その結果, $\mathrm{BaFe}$ テープは MPテープを超える長 期化学的安定性を持つことが明らかになった。これは，今 後 $\mathrm{BaFe}$ テープをリニアシステム用の高記録密度磁気テー プとして，実用化していく上で化学的安定性については全 く問題がなく十分に市場での保存耐久性があることを意味 している.

\section{References}

1) J. Gantz and D. Reinsel, "The Digital Universe Decade - Are You Ready?", (2010) available at http://idcdocserv.com/925 (As of Sep. 27, 2010).

2) T. Inoue, K. Nakiri, H. Mitsuhashi, M. Fukumoto, T. Doi, Y. Sasaki, M. Kishimoto, IEEE Trans. Magn., 42, 465 (2006).

3) T. Nagata, T. Harasawa, M. Oyanagi, N. Abe, and S. Saito, IEEE Trans. Magn., 42, 2312 (2006).

4) K. Motohashi, T. Sato, T. Samoto, N. Ikeda, T. Sato, H. Ono, and S. Onodera, IEEE Trans. Magn., 43, 2325 (2007).

5) D. Berman et al., IEEE Trans. Magn., 43, 3502 (2007).

6) S. Matsunuma, T. Inoue, T. Doi, T. Matsuu, A. Hashimoto, H. Fujiura, K. Hirata, S. Nakagawa, IEEE Trans. Magn., 44, 3561 (2008)

7) M. L. Watson, R. A. Beard and, S. M. Kientz, IEEE Trans. Magn., 44, 3568 (2008).

8) D. Berman, V. H. Chembrolu, T. Topuria, S. Matsunuma, T. Inoue, T. Doi, T. Matsuu, A. Hashimoto, K. Hirata, and S. 
Nakagawa, IEEE Trans. Magn., 45, 3584 (2009).

9) S. Matsunuma, T. Inoue, T. Doi, T. Matsuu, A. Hashimoto, K. Hirata, S. Nakagawa, IEEE Trans. Magn., 45 , 3598 (2009).

10) P.-O. Jubert, D. Berman, W. Imaino, T. Sato, N. Ikeda, D. Shiga, K. Motohashi, H. Ono, and S. Onodera, IEEE Trans. Magn., 45, 3601 (2009).

11) S. Ölçer, E. Eleftheriou, R. A. Hutchins, H. Noguchi, M. Asai, and H. Takano, IEEE Trans. Magn., 45, 3765 (2009).

12) A. Matsumoto, Y. Murata, A. Musha, S. Matsubaguchi, and O. Shimizu, IEEE Trans. Magn., 46, 1208 (2010).

13) O. Shimizu, T. Harasawa, and M. Oyanagi, IEEE Trans. Magn., 46, 1607 (2010).

14) T. Harasawa, R. Suzuki, O. Shimizu, S. Ölçer, and E. Eleftheriou, IEEE Trans. Magn., 46, 1894 (2010).

15) G. Cherubini et al. " $29.5 \mathrm{~Gb} / \mathrm{in}^{2}$ Recording Areal Density on Barium Ferrite Tape" presented at the $21^{\text {st }}$ magnetic recording conference TMRC-2010, La Jolla California, 2010 C3, and to be published in IEEE Trans. Magn.
16) S. Matsunuma, T. Inoue, T. Doi,, T. Watanabe, S. Gomi, Y. Mashiko, K. Hirata, and S. Nakagawa, Digests of 34th Annual. Conf. on Magn. Jpn 5aA-10 (2010) (in Japanese).

17) T. Fujiwara, M. Isshiki, Y. Koike, and T. Oguchi, IEEE Trans. Magn., 18, 1200 (1982).

18) O. Kubo, T. Ido, and H. Yokoyama, IEEE Trans. Magn., 18, 1122 (1982).

19) Y. Murata and K. Inoue, J. Magn. Soc. Jpn., 34182 (2010) (in Japanese)

20) W. H. Abbott, IEEE Trans. Components, Hybrids, Manuf. Technol. 11, 22 (1988).

21) P. J. Sides, G. Spratt, and J. P. Kampf, IEEE Trans. Magn., 30, 4059 (1994).

22) T. Iwano and K. Kobayashi, IEEE Trans. Magn., 41, 3010 (2005).

23) D. C. Abbott, R. A. Frechette, G. Haynes, and D. W. Romm, "Shelf-Life Evaluation of Nickel/Palladium Lead Finish for Integrated Circuits" Texas Instruments Application Notes, (1998) available at http://focus.ti.com/lit/an/szza002/szza002.pdf (As of Sep. 27, 2010). 2010年10月13日受理，2011年 1月17日採録 